\title{
Isoptericola halotolerans sp. nov., a novel actinobacterium isolated from saline soil from Qinghai Province, north-west China
}

\author{
Correspondence \\ Wen-Jun Li \\ wjli@ynu.edu.cn or \\ lihxu@ynu.edu.cn
}

\author{
Yu-Qin Zhang, ${ }^{1,2}$ Peter Schumann, ${ }^{3}$ Wen-Jun Li, ${ }^{1}$ Guo-Zhong Chen, ${ }^{1}$ \\ Xin-Peng Tian, ${ }^{1}$ Erko Stackebrandt, ${ }^{3} \mathrm{Li}^{-H u a} \mathrm{Xu}^{1}$ and Cheng-Lin Jiang ${ }^{1}$
}

${ }^{1}$ The Key Laboratory for Microbial Resources of Ministry of Education, Yunnan Institute of Microbiology, Yunnan University, Kunming, Yunnan, 650091, People's Republic of China

${ }^{2}$ Institute of Medicinal Biotechnology, Chinese Academy of Medical Sciences and Peking Union Medical College, Beijing, 100050, People's Republic of China

${ }^{3} \mathrm{DSMZ}$ - Deutsche Sammlung von Mikroorganismen und Zellkulturen GmbH, Mascheroder Weg 1b, D-38124 Braunschweig, Germany

\begin{abstract}
A Gram-positive, non-motile actinobacterium, designated strain YIM $70177^{\top}$, was isolated from a saline soil sample from Qinghai Province, north-west China. Phylogenetic analysis of this organism based on $16 \mathrm{~S}$ rRNA gene sequences revealed $98.3 \%$ similarity to /soptericola variabilis DSM $10177^{\top}$. Chemotaxonomic data determined for the isolate, such as the peptidoglycan type $A 4 \alpha$, variation L-Lys-D-Asp, supported the placement of strain YIM $70177^{\top}$ within the genus Isoptericola. Galactose was detected as cell wall sugar. Phospholipids identified were phosphatidylinositol, phosphatidylglycerol and diphosphatidylglycerol, and the predominant menaquinones were MK- $9\left(\mathrm{H}_{4}\right)$ and $M K-9\left(\mathrm{H}_{2}\right)$. The major fatty acids were ai- $\mathrm{C}_{15: 0}, \mathrm{C}_{16: 0}$, ai- $\mathrm{C}_{17: 0}$ and $\mathrm{i}_{15: 0}$. The DNA $\mathrm{G}+\mathrm{C}$ content was $72 \cdot 8 \mathrm{~mol} \%$. The low level of DNA-DNA relatedness $(27 \cdot 4 \%)$ to $I$. variabilis DSM $10177^{\top}$ in combination with differentiating chemotaxonomic and physiological data demonstrated that the isolate YIM $70177^{\top}$ should be classified as representing a novel species of the genus Isoptericola. The name /soptericola halotolerans sp. nov. is proposed, with strain YIM $70177^{\top}$ (=DSM $16376^{\top}=$ KCTC $19046^{\top}$ ) as the type strain.
\end{abstract}

Cellulosimicrobium variabile Bakalidou et al. 2002 was reclassified as Isoptericola variabilis by Stackebrandt et al. (2004) because of differences in the 16S rRNA gene sequence (96.6\% similarity), cell-wall sugar (glucose rather than fucose) and in the amino acid composition of the peptidoglycan (L-Lys-Asp versus L-Lys-Ser-Asp) in comparison with Cellulosimicrobium cellulans (Schumann et al., 2001). Isolate YIM $70177^{\mathrm{T}}$ from saline soil sampled in China is here proposed as the type strain of a novel species of the genus Isoptericola, Isoptericola halotolerans sp. nov.

Strain YIM $70177^{\mathrm{T}}$ was isolated by using the dilution plating method on a modified Horikoshi medium (Horikoshi \& Grant, 1998). This medium contained $\left(1^{-1}\right) 10 \cdot 0$ g glucose, $5.0 \mathrm{~g}$ peptone, $5.0 \mathrm{~g}$ yeast extract, $1.0 \mathrm{~g} \mathrm{~K} \mathrm{KPO}_{4} .3 \mathrm{H}_{2} \mathrm{O}$, $0 \cdot 2 \mathrm{~g} \mathrm{MgSO}_{4} \cdot 7 \mathrm{H}_{2} \mathrm{O}, 200 \mathrm{~g} \mathrm{NaCl}, 10 \cdot 0 \mathrm{~g} \mathrm{Na}_{2} \mathrm{CO}_{3}$ and $15 \cdot 0 \mathrm{~g}$ agar. $\mathrm{NaCl}$ and sodium carbonate were sterilized separately before addition to the medium. The $\mathrm{pH}$ of the medium was

Published online ahead of print on 22 April 2005 as DOI 10.1099/ ijs.0.63641-0.

The GenBank/EMBL/DDBJ accession number for the $16 \mathrm{~S}$ rRNA gene sequence of strain YIM $70177^{\top}$ is AY789835. adjusted to $10 \cdot 0-10 \cdot 5$ using $\mathrm{NaHCO}_{3} / \mathrm{Na}_{2} \mathrm{CO}_{3}$ buffer. Strain YIM $70177^{\mathrm{T}}$ was maintained on ISP 5 agar slants containing $10 \%(\mathrm{w} / \mathrm{v}) \mathrm{NaCl}$ at $4{ }^{\circ} \mathrm{C}$ and as $20 \%(\mathrm{w} / \mathrm{v})$ glycerol suspensions at $-20{ }^{\circ} \mathrm{C}$. Biomass for chemical and molecular studies was obtained by cultivation in shaken flasks (about 150 r.p.m.) using modified ISP 5 broth [10\% $(\mathrm{w} / \mathrm{v}) \mathrm{NaCl}, \mathrm{pH} 7 \cdot 0$ ] at $28^{\circ} \mathrm{C}$ for 1 week.

Gram staining was carried out by the standard Gram reaction and was confirmed by using the $\mathrm{KOH}$ lysis test method (Cerny, 1978). Morphology and motility were examined by light microscopy (model $\mathrm{BH} 2$; Olympus) and electron microscopy (JEM-1010 electron microscope) using cells from exponentially growing cultures. Colony morphology was observed on marine agar (MA), ISP 5 medium containing $10 \% \mathrm{NaCl}$ and trypticase soy agar (TSA) containing $10 \% \mathrm{NaCl}$ after incubation at $28^{\circ} \mathrm{C}$ for 3 days. Colony colour was determined by comparing the cultures with the most suitable colour chips from the ISCC-NBS colour charts (Kelly, 1964). Growth temperature was tested at 4, 10, 28, $37,40,45$ and $55^{\circ} \mathrm{C}$ on the same medium. $\mathrm{pH}$ and $\mathrm{NaCl}$ tolerances were examined as described by Tang et al. (2003). Metabolic properties were determined using API ID $32 \mathrm{E}$ 
test kits (bioMérieux) according to the manufacturer's instructions. Other physiological and biochemical tests were performed as described by Gonzalez et al. (1978).

Growth of strain YIM $70177^{\mathrm{T}}$ was aerobic and cells stained Gram-positive. Coccoid and rod-shaped cells were observed, but neither flagella nor spores were found. Pale-yellow colonies with a smooth surface and a maximal diameter of approximately $1 \mathrm{~mm}$ were formed on MA and TSA containing $10 \% \mathrm{NaCl}$ after incubation for $48 \mathrm{~h}$ at $28^{\circ} \mathrm{C}$.

Strain YIM $70177^{\mathrm{T}}$ grew well at 28 and $37^{\circ} \mathrm{C}$; only slow growth occurred at 4 and $45^{\circ} \mathrm{C}$. Growth was observed at initial pH values between 6 and 10 and on TSA containing $0-25 \% \mathrm{NaCl}$. The strain grew optimally at $28^{\circ} \mathrm{C}$, at $\mathrm{pH} \mathrm{8-9}$ and in the presence of $10 \% \mathrm{NaCl}$. Detailed physiological and biochemical characteristics of the strain are given in Table 1 and in the species description below.

The chemotaxonomic properties of strain YIM $70177^{\mathrm{T}}$, including peptidoglycan type, purified cell-wall sugars, phospholipids, menaquinones and whole-cell fatty acid pattern, were analysed as described by Li et al. (2004). The peptidoglycan type was A4 $\alpha$, variation L-Lys-D-Asp. Galactose was detected in the purified cell wall. Phospholipids identified were phosphatidylinositol, phosphatidylglycerol and diphosphatidylglycerol. The menaquinones were
MK-9 $\left(\mathrm{H}_{4}\right)$, MK-9 $\left(\mathrm{H}_{2}\right)$, MK-8 $\left(\mathrm{H}_{4}\right)$ and MK-9 (ratio of peak areas, $15: 10: 2: 1)$. The major fatty acids were ai- $\mathrm{C}_{15: 0}$, $\mathrm{C}_{16: 0}$, ai- $\mathrm{C}_{17: 0}$ and $\mathrm{i}-\mathrm{C}_{15: 0}$; the detailed profile is given in the species description.

Extraction of genomic DNA and PCR amplification of the $16 \mathrm{~S}$ rRNA gene were performed as described by $\mathrm{Xu}$ et al. (2003). Multiple alignments with sequences of the most closely related actinobacteria and calculations of levels of $16 \mathrm{~S}$ rRNA gene sequence similarity were carried out using CLUSTAL X (Thompson et al., 1997). A phylogenetic tree was reconstructed using the neighbour-joining method of Saitou \& Nei (1987) from $K_{\text {nuc }}$ values (Kimura, 1980, 1983) using MEGA version 2.1 (Kumar et al., 2001). The topology of the phylogenetic tree was evaluated by the bootstrap resampling method of Felsenstein (1985) with 1000 replicates.

The 16S rRNA gene sequence (1382 bp) for strain YIM $70177^{\mathrm{T}}$ was determined. Phylogenetic analysis of strain YIM $70177^{\mathrm{T}}$ revealed that it was most closely related to $I$. variabilis DSM $10177^{\mathrm{T}}$ with a $16 \mathrm{~S}$ rRNA gene sequence similarity of $98 \cdot 3 \%$, and the two strains formed a distinct subclade in the family Promicromonosporaceae (Fig. 1).

The $\mathrm{G}+\mathrm{C}$ content of the DNA of strain YIM $70177^{\mathrm{T}}$ was $72 \cdot 8 \mathrm{~mol} \%$ as determined by reversed-phase HPLC of

Table 1. Differentiating phenotypic characteristics of strain YIM $70177^{\top}$ and I. variabilis DSM $10177^{\top}$

The following phenotypic characteristics are the same for both strains. Gram-positive, non-motile, coccoid or rod-shaped cells. Catalase-positive and oxidase-negative. Milk coagulation, melanin production, $\mathrm{H}_{2} \mathrm{~S}$, VogesProskauer and indole production are negative; Tweens 20 and 80, casein and starch are not decomposed. Activity for $\alpha$-galactosidase, $\beta$-glucosidase, $\beta$-galactosidase, $\alpha$-maltosidase and lipase and growth on cellulose are positive. Urease, arginine dihydrolase and ornithine decarboxylase are negative. The following substrates are utilized as sole carbon sources for growth: maltose, sucrose, mannose, fructose, salicin and galactose; rhamnose, acetamide, inositol, mannitol, adonitol and sorbitol are not utilized.

\begin{tabular}{|c|c|c|}
\hline Characteristic & YIM $70177^{\mathrm{T}}$ & DSM $10177^{\mathrm{T}}$ \\
\hline Colony pigmentation (PYGV medium) & Pale-yellow & Yellow \\
\hline Methyl red test & + & - \\
\hline Acid production from maltose & + & - \\
\hline Utilization of trehalose & - & + \\
\hline \multicolumn{3}{|l|}{ Enzyme activities } \\
\hline Lysine decarboxylase & - & + \\
\hline$N$-Acetyl-glucosaminidase & + & - \\
\hline L-Aspartic arylamidase & - & + \\
\hline Cell-wall sugar $(s)^{\star}$ & Gal & Rha, Gal, Glc \\
\hline Major menaquinone(s) & MK-9 $\left(\mathrm{H}_{4}\right)$, MK- $9\left(\mathrm{H}_{2}\right)$ & MK-9 $\left(\mathrm{H}_{4}\right)$ \\
\hline Phospholipids $\dagger$ & PI, PG, DPG & PI, PG, DPG, PL \\
\hline \multirow[t]{2}{*}{ Major fatty acids } & ai- $C_{15: 0}, \mathrm{i}-\mathrm{C}_{15: 0}$ & ai- $C_{15: 0}, \mathrm{i}-\mathrm{C}_{15: 0}, \mathrm{C}_{14: 0}$, \\
\hline & $\mathrm{C}_{16: 0}$, ai- $\mathrm{C}_{17: 0}$ & $\mathrm{C}_{16: 0}, \mathrm{i}-\mathrm{C}_{16: 0}$, ai- $\mathrm{C}_{17: 0}$ \\
\hline DNA G $+\mathrm{C}$ content $(\mathrm{mol} \%)$ & $72 \cdot 8$ & $70-72$ \\
\hline
\end{tabular}

${ }^{*}$ Gal, Galactose; Glc, glucose; Rha, rhamnose.

$\dagger$ DPG, Diphosphatidylglycerol; PG, phosphatidylglycerol; PI, phosphatidylinositol; PL, unknown phospholipids. 


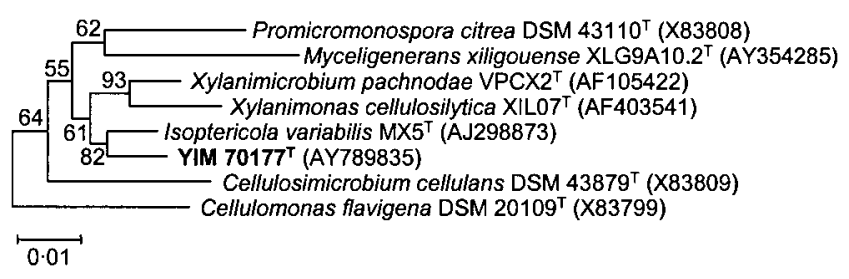

Fig. 1. Phylogenetic dendrogram obtained by distance matrix analysis of 16S rRNA gene sequences, showing the position of strain YIM $70177^{\top}$ and of its phylogenetic neighbours. Numbers on branch nodes are bootstrap percentages (1000 resamplings; only values over $50 \%$ are given). The sequence of Streptomyces megasporus DSM $41476^{\top}$ (Z68100) was used as the root. Bar, $1 \%$ sequence divergence.

nucleosides according to Mesbah et al. (1989). DNA-DNA relatedness was studied using the optical renaturation method (De Ley et al., 1970; Huß et al., 1983; Jahnke, 1992) by using a UV-VIS spectrophotometer model UV1601 (Shimadzu). The level of DNA-DNA relatedness between YIM $70177^{\mathrm{T}}$ and I. variabilis DSM $10177^{\mathrm{T}}$ was $27 \cdot 4 \%$ (repeated twice; the original recorded values were $25 \cdot 8$ and $29 \cdot 0 \%$ ).

The results of $16 \mathrm{~S}$ rRNA gene sequence analysis clearly demonstrate that strain YIM $70177^{\mathrm{T}}$ represents a member of the genus Isoptericola. Similarities in morphological characteristics, peptidoglycan type and DNA G $+\mathrm{C}$ content to I. variabilis DSM $10177^{\mathrm{T}}$ support the inclusion of strain YIM $70177^{\mathrm{T}}$ within the genus Isoptericola. However, strain YIM $70177^{\mathrm{T}}$ differs from I. variabilis DSM $10177^{\mathrm{T}}$ in components of the cell-wall sugars, phospholipids, menaquinones, cellular fatty acids and some physiological and enzymic properties (see Table 1). The level of DNA-DNA relatedness of $27 \cdot 4 \%$ between YIM $70177^{\mathrm{T}}$ and $I$. variabilis DSM $10177^{\mathrm{T}}$ is significantly lower than $70 \%$, the threshold value considered for the delineation of genomic species (Wayne et al., 1987). These results support the proposal of a novel species, for which the name Isoptericola halotolerans sp. nov. is proposed.

\section{Description of Isoptericola halotolerans sp. nov.}

Isoptericola halotolerans (ha.lo.to'le.rans. Gr. n. hals salt; L. part. adj. tolerans tolerating; N.L. part. adj. halotolerans salttolerating, referring to the organism's ability to tolerate high salt concentrations).

Cells are Gram-positive, coccoid or rod-shaped, non-motile and do not form spores. Primary mycelium is formed. Colonies are pale-yellow, circular, opaque and approximately $1.0 \mathrm{~mm}$ in diameter after $24 \mathrm{~h}$ growth at $28^{\circ} \mathrm{C}$. Optimal growth occurs at $10 \% \mathrm{NaCl}, \mathrm{pH} 8 \cdot 0-9 \cdot 0$ and $28{ }^{\circ} \mathrm{C}$. In addition to the properties listed in Table 1 , the strain is negative for gelatin liquefaction, ammonia production, milk peptonization and starch hydrolysis, but positive for methyl red test and nitrate reduction. The following substrates are utilized: glucose, ribose, arabinose, maltose, cellobiose, trehalose, sorbitol, lactose, xylose and dextrin. The peptidoglycan type is A $4 \alpha$, variation L-Lys$\mathrm{D}$-Asp. The cell-wall sugar is galactose. Phospholipids are phosphatidylinositol, phosphatidylglycerol and diphosphatidylglycerol. The predominant menaquinones are MK$9\left(\mathrm{H}_{4}\right)$ and MK-9 $\left(\mathrm{H}_{2}\right)$. The cellular fatty acids are ai- $\mathrm{C}_{15: 0}$ $(54 \cdot 46 \%), \mathrm{C}_{16: 0}(20 \cdot 05 \%)$, ai- $\mathrm{C}_{17: 0}(10 \cdot 69 \%), \mathrm{i}-\mathrm{C}_{15: 0}$ $(7 \cdot 02 \%), \mathrm{C}_{14: 0}(2 \cdot 33 \%), \mathrm{i}-\mathrm{C}_{16: 0}(1 \cdot 44 \%), \mathrm{C}_{15: 0}(0 \cdot 98 \%)$, $\mathrm{C}_{17: 0}(0 \cdot 61 \%), \mathrm{C}_{18: 0}(0 \cdot 36 \%), \mathrm{i}-\mathrm{C}_{14: 0}(0 \cdot 64 \%), \mathrm{i}-\mathrm{C}_{17: 0}$ $(0 \cdot 51 \%)$ and ai- $\mathrm{C}_{15: 1}(0 \cdot 51 \%)$. The $\mathrm{G}+\mathrm{C}$ content of the DNA of the type strain is $72 \cdot 8 \mathrm{~mol} \%$.

The type strain, YIM $70177^{\mathrm{T}}\left(=\mathrm{DSM} 16376^{\mathrm{T}}=\mathrm{KCTC}\right.$ $\left.19046^{\mathrm{T}}\right)$, was isolated from a saline soil sample collected from Qinghai Province, north-west China.

\section{Acknowledgements}

This research was supported by National Basic Research Program of China (project no. 2004CB719601), National Natural Science Foundation of China (project no. 30270004) and Yunnan Provincial Natural Science Foundation (project no. 2004 C0002Q).

\section{References}

Bakalidou, A., Kämpfer, P., Berchtold, M., Kuhnigk, T., Wenzel, M. \& König, H. (2002). Cellulosimicrobium variabile sp. nov., a cellulolytic bacterium from the hindgut of the termite Mastotermes darwiniensis. Int J Syst Evol Microbiol 52, 1185-1192.

Cerny, G. (1978). Studies on aminopeptidase for the distinction of Gram-negative from Gram-positive bacteria. Eur J Appl Microbiol Biotechnol 5, 113-122.

De Ley, J., Cattoir, H. \& Reynaerts, A. (1970). The quantitative measurement of DNA hybridization from renaturation rates. Eur J Biochem 12, 133-142.

Felsenstein, J. (1985). Conference limits on phylogenies: an approach using the bootstrap. Evolution 39, 783-789.

Gonzalez, C., Gutierrez, C. \& Ramirez, C. (1978). Halobacterium vallismortis sp. nov., an amylolytic and carbohydrate-metabolizing, extremely halophilic bacterium. Can J Microbiol 24, 710-715.

Horikoshi, K. \& Grant, W. D. (editors) (1998). Extremophiles: Microbial Life in Extreme Environments. New York: Wiley.

Huß, V. A. R., Festl, H. \& Schleifer, K. H. (1983). Studies on the spectrophotometric determination of DNA hybridization from renaturation rates. Syst Appl Microbiol 4, 184-192.

Jahnke, K.-D. (1992). BASIC computer program for evaluation of spectroscopic DNA renaturation data from GILFORD SYSTEM 2600 spectrophotometer on a PC/XT/AT type personal computer. J Microbiol Methods 15, 61-73.

Kelly, K. L. (1964). Inter-society Color Council - National Bureau of Standards Color-Name Charts Illustrated With Centroid Colors. Washington, DC: US Government Printing Office.

Kimura, M. (1980). A simple method for estimating evolutionary rates of base substitutions through comparative studies of nucleotide sequences. J Mol Evol 16, 111-120.

Kimura, M. (1983). The Neutral Theory of Molecular Evolution. Cambridge: Cambridge University Press. 
Kumar, S., Tamura, K., Jakobsen, I.-B. \& Nei, M. (2001). MEGA2: molecular evolutionary genetics analysis software. Bioinformatics $\mathbf{1 7}$, 1244-1245.

Li, W.-J., Chen, H.-H., Xu, P., Zhang, Y.-Q., Schumann, P., Tang, S.-K., Xu, L.-H. \& Jiang, C.-L. (2004). Yania halotolerans gen. nov., sp. nov., a novel member of the suborder Micrococcineae from saline soil in China. Int J Syst Evol Microbiol 54, 525-531.

Mesbah, M., Premachandran, U. \& Whitman, W. B. (1989). Precise measurement of the $\mathrm{G}+\mathrm{C}$ content of deoxyribonucleic acid by high-performance liquid chromatography. Int J Syst Bacteriol 39, 159-167.

Saitou, N. \& Nei, M. (1987). The neighbor-joining method: a new method for reconstructing phylogenetic trees. Mol Biol Evol 4, 406-425.

Schumann, P., Weiss, N. \& Stackebrandt, E. (2001). Reclassification of Cellulomonas cellulans (Stackebrandt and Keddie 1986) as Cellulosimicrobium cellulans gen. nov., comb. nov. Int J Syst Evol Microbiol 51, 1007-1010.
Stackebrandt, E., Schumann, P. \& Cui, X.-L. (2004). Reclassification of Cellulosimicrobium variabile Bakalidou et al. 2002 as Isoptericola variabilis gen. nov., comb. nov. Int J Syst Evol Microbiol 54, 685-688.

Tang, S. K., Li, W. J., Wang, D., Zhang, Y. G., Xu, L. H. \& Jiang, C. L. (2003). Studies of the biological characteristics of some halophilic and halotolerant actinomycetes isolated from saline and alkaline soils. Actinomycetologica 17, 6-10.

Thompson, J. D., Gibson, T. J., Plewniak, F., Jeanmougin, F. \& Higgins, D. G. (1997). The CLUSTAL_X Windows interface: flexible strategies for multiple sequence alignment aided by quality analysis tools. Nucleic Acids Res 25, 4876-4882.

Wayne, L. G., Brenner, D. J., Colwell, R. R. \& 9 other authors (1987) Report of the ad hoc committee on reconciliation of approaches to bacterial systematics. Int J Syst Bacteriol 37, 463-464.

Xu, P., Li, W. J., Xu, L. H. \& Jiang, C. L. (2003). A microwave-based method for genomic DNA extraction from Actinomycetes. Microbiology 30, 73-75 (in Chinese). 